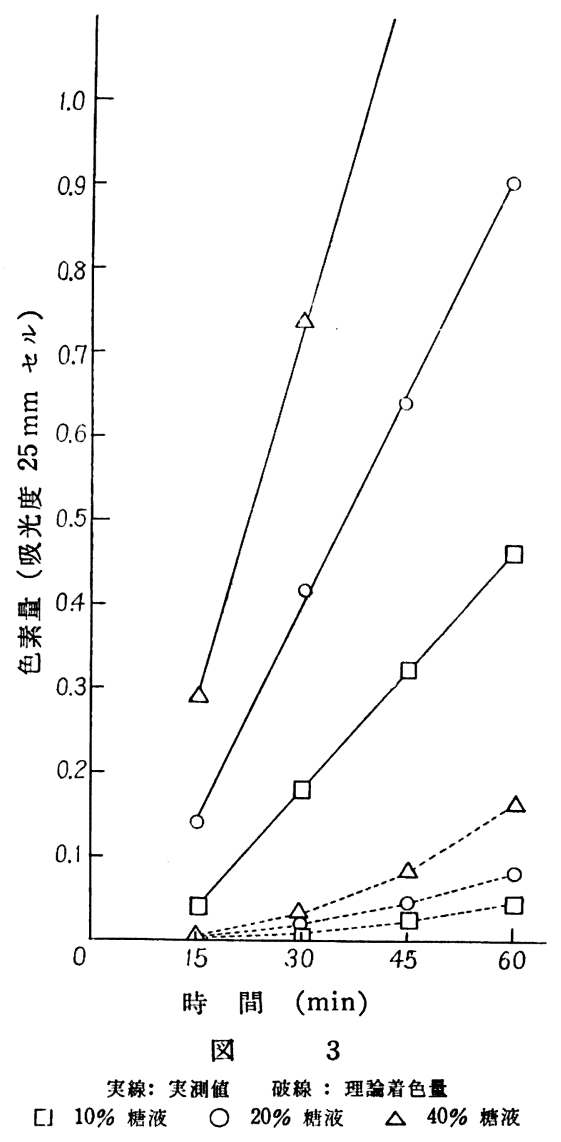

しかし罒 2 で示されるように着色量は時間と直線関係にあり, 着
色がこのような理論で行なわれないことを示すことになろう。 $2 \cdot 2 \cdot 3$ の結果から $\mathrm{HMF}$ を $1.15 \mathrm{~N}$ 塩酸溶液として加熱したと きの $\alpha$ の值を計算すると表 6 の結果より $1 \mathrm{mg}$ の HMF が 1 分 間に生成する色素量は $2.5 \times 10^{-4}$ となる。すなわち

$$
\alpha=2.5 \times 10^{-4}
$$

ただし $25 \mathrm{~mm}$ セルの吸光度として表わす

これを(10) 式に代入すると

$$
E=(1 / 2) \times 2.5 \times 10^{-4} \times a K \times(126) \times T_{0}^{2}
$$

ただし 126 は HMF の分子量

（12）式はブドウ糖を $1.15 \mathrm{~N}$ 塩酸溶液で $100^{\circ} \mathrm{C}$ に加熱した場合， もし着色過程がブドウ糖 $\rightarrow \mathrm{HMF} \rightarrow$ 色という機構で行なわれ，HM $\mathrm{F}$ が単独に色の原因になるとした場合の理論着色量を示すことに なる。

$1.15 \mathrm{~N}$ 塩酸にブドウ糖を溶かし, $100^{\circ} \mathrm{C} て ゙$ 加熱した場合の生 成色素量の実測値と（12）式で得られる理論着色量の値を求めた 結果を図 3 に示す。

因 3 の結果, 理論着色量は実測值よりはるかに少ないことが判 明した。

以上の結果を総括すればブドウ糖の酸性溶液を加熱する場合に 生成する色と HMF とは密接な関係にあるが，HMF のみの着色 量から考えると HMF を色の原因とすることに大いに疑問を持 つ。すなわち，糖液の着色は HMF を通るもの以外の別の過程を 通って行なわれるものがあるか，または HMF を通って色になる にしても HMF $\rightarrow$ 色の過程に未知の着色原因が存在するとしなけ ればならない。少なくとも HMF のみを単独に色の原因とするこ とはできないるのと考えられる。

(昭和 34 年 4 月, 日本化学会第 12 年会講演)

\title{
フトトゥ糖水溶液の pHと加熱による屇色との関係
}

（昭 和 34 年 7 月 10 日 受 理）

吉 弘 芳 郎・中 村 亦夫*

前報1に引きつづき，ブドウ糖水溶液を加熱した場合に起る着色がブドウ糖から生成される5-オキシメチルフルフラー ル（以下 HMF と略す）によるすのであるかど5かについてを明らかにする目的で, $\mathrm{pH} 2 \sim 7$ のブドウ糖水溶液を加熱 し, 着色量, $\mathrm{HMF}$ 量を求め, HMF 水溶液を同様に処理し，その着色量および残存 HMF 量を求めた。

またブドウ糖水溶夜を加熱した場合に生成される HMF 量とほぼ同量の HMF をブドウ糖液にあらかじめ加えて加熱

し着色を行ないブドウ糖単独の溶液の着色量と比較した。

その結果，液の $\mathrm{pH}$ は着色に重要な関係があり $\mathrm{pH} 3 \sim 4$ で着色が最小となる。 $\mathrm{HMF}$ の生成と $\mathrm{pH}$ の関係には特異な あのがあり, $\mathrm{HMF}$ 生成量を示す曲線は $\mathrm{pH} 3.6$ 付近で一つの極大点が存在する。

$\mathrm{H} . \mathrm{MF}$ 水溶液はほとんど着色せず，また HMF をブドウ糖に加えた場合も着色量はそれほど增大しない。これらから HMF は色の因子ではないと推定される。

\section{1 腥}

デンプン糖工業に拉いて, 酸糖化液を中和後活性炭で脱色した 無色の清澄桾液を，そのまま煮詰工程に移した場合には必す桾液 が褐色化することは周知である。このように糖液が着色する原因 についての研究はすでにいろいろと多く行なわれてきた。すなわ

* 東京大学生産技術研究所: 千葉市弥生町.

1) 吉弘, 中村, 工化 63, 157 (1960).
ち，糖液の着色を促進する物質として特にタンパク質，アミノ酸 などの有機窒素化合物があげられ，糖とこれらの物質による褐色 化はいわゆる Maillard reaction として数多くの研究2)がある。 また，ある種の無機塩は糖の褐色化を促進することも報告され， これらの物質をブドウ糖溶液に加えて熱し，着色をしらへた報告 は3)かなりの数にのぼる。

2) たとえば A. Gottschalk, S. M. Partridge, Nature 165 , 684 (1950). 
一方, ブドウ糖液の着色機構を論じた報告は比較的少なく, 着 色の原因については全く不明といっても過言ではない。

Singh4) らはブドウ糖夜の着色はブドウ糖から生成される5-オ キシメチルフルフラール (HMF) が主原因であるとし, Wolfrom ${ }^{5)}$ らはブドウ糖とグリシンの反応による着色も HMF が重要な先駆 物質であるとした。

しかるに著者らは HMF の量の問題を考慮してこれらの説に疑 問をいだき，すでに前報1に扎いて，ブドウ桾の酸性溶液を加熱 した場合に生成する色素量と HMF 量の関係をしらべ, HMF の みを単独に色の原因とすることに疑問を持つことを報告した。

Lindemann ${ }^{6}$ ) は市販水飴を眝蔵したときに生ずる色は水飴中 に含まれている HMF の消失を伴ならことを報告した。しかし， pH 3〜7 のいわゆる中性と称される程度のブドウ糖溶液を加熱し たとき生ずる色が HMF によるるのであるかどうかは不明であ る。すなわち, $\mathrm{pH} 3 \sim 7$ で糖液を加熱したとさの着色量と $\mathrm{HMF}$ 量の関係を報告したものはない。

著者らは酸性糖液を加熱したとき液の $\mathrm{pH}$ が着色と $\mathrm{HMF}$ の 生成に 重要な影響を持つことを前報で報告した。いわゆる中性 の糖液を加熱したときの $\mathrm{pH}$ と着色については Schröeder7), Wolfrom $\left.^{8}\right)$ らの報告があげられるが, いずれも Maillard reaction に打ける $\mathrm{pH}$ の影響を報告したもので，ブドウ糖液を単独に加熱 したときの着色量と HMF 量の関係にはふれていない。

著者らはこれらの関俰を明らかにし，前報に引きつつき色の原 因としての HMF の役割を検討する目的で，種々の $\mathrm{pH}$ のブドウ 糖溶液を加熱し，着色量と反応液中に残る $\mathrm{HMF}$ 量を求め，別に 既知濃度の HMF 溶液について桾液の加熱と同条件で処理し，そ の着色量と残存 $\mathrm{HMF}$ 量を求め比較検討を行なった。

その結果, ブドウ糖液を加熱したときは液の $\mathrm{pH}$ と着色量およ び生成 HMF 量との間に注目すべき関係のあることを認め，さら に前報同様に HMF のみが単独に着色の原因にはなり得ないこと を羿めた。

\section{2 実 験 方 法}

局方注射用ブドウ糖を脱塩水にて溶解し $40 \mathrm{~g} / 100 \mathrm{cc}$ 溶液とす る。これに等量の緩衝液（pH 2〜7）を加え，ブドウ糖の緩衝溶 液とした。この溶液の $\mathrm{pH}$ をあらかじめ測定しておく。これを各 $10 \mathrm{cc} \sim 5.0 \mathrm{cc}$ ずつ試験管に細分し，一定時間加熱し，着色を行 なった。

緩衝液は酢酸ナトリウム, 塩酸混合溶液 (Walpole ${ }^{9}$ ) の緩衝液) および酒石酸, 酒石酸ナトリウム混合液 (Michaelis $\left.{ }^{10}\right)$ の楥㣫液) を用いた。加熱温度は $100^{\circ} \mathrm{C}$ (沸腾湯浴中)，および $134^{\circ} \mathrm{C}$ (オ ートクレーブ中）を採用した。加熱反応後は反応液に $20 \%$ 炭酸

3）たとえば 玉㯰，工化 56，410 (1953).

4) B. Singh, G. R. Dean, S. M. Cantor, J. Am. Chem. Soc. 70, 517 (1948).

5) M. L. Wolfrom, R. D. Schnetz, L. F. Cavalieri, ibid. 71, 3518 (1949).

6) E. Lindemann, Stärke 7, 86 (1955).

7) L. J. Schröeder, M Iscobellis, A.H. Smith, J. Biol. Chem. 212, 973 (1955); Chem. Abst. 49, $7079 \mathrm{~g}$.

8) M. L. Wolfrom, D. Kolb, A. W. Langer, J. Am. Chem. Soc. 75, 3471 (1953).

9) 化学実験学 第 2 部, 12 巻 p. 143 河出書房.

10) 化学実験学 第 2 部, 12 卷 p. 131 河出書房.
ナトリウム水溶液を加光， $\mathrm{pH}$ を 10.5〜10.8 にし，25 cc に定 容後，ただちにその着色および HMF 量を測定した。

測 定 法

$\mathrm{pH}$ ：前報1に同じ東垔電波製 $\mathrm{pH}$ 計による。

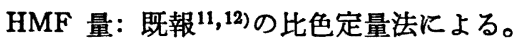

色素量：前報に同じ。すなわち，日立製 EPO-A 型光電光度計 を使用し, 主波長 $460 \mathrm{~m} \mu$ のフィルター（フィルター番号B）を 使用し, 蒸留水を対照にし溶液の吸光度を測定し, 吸光度の大小 で色素量の大小を定めた。

\section{3 実験結果と考察}

\section{$3 \cdot 1$ フドウ糖溶液の加熱について}

$1 \mathrm{~N}$ 酢酸ナトリウム水溶液と $1 \mathrm{~N}$ 塩酸を種々の割合に混合し た緩衝液を用いて実験した結果を図 1 に示す。加熱は $135^{\circ} \mathrm{C}(2$ atm）で 60 分間行なったものである。

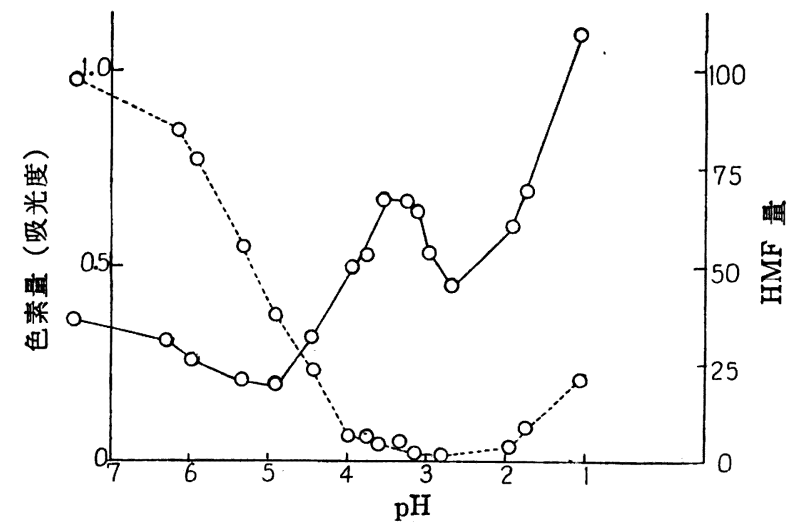

図 1

実線：HMF $(\mathrm{mg} / 100 \mathrm{cc})$ 破線：色索量 $10 \mathrm{~mm}$ 七儿

四 1 で判明するように色素量および HMF 量は以下では前報に のべたように $\mathrm{pH}$ が低いほど増加している。 $\mathrm{pH} 3$ 以上で $\mathrm{pH}$ 上がるにつれて色素量はしだいに增加し， $\mathrm{pH} 4$ 以上では急速に增 加する。しかるに, HMF は pH 3.5 付近で一つの極大值を特つが， その量を示す曲線は色素量を示す曲線と大いに異なるところであ る。すなわち, 色素の生成は $\mathrm{pH} 3$ 付近が最低であるに反し, $\mathrm{HMF}$ の反応液中の残存量は $\mathrm{pH} 1 \sim 7$ で極めて特異な存在のしか たを示す。これらの関係を再確認するため, 同じ緩衝液を使用 し，加熱条件をかえて実験した結果を図 2 に示す。

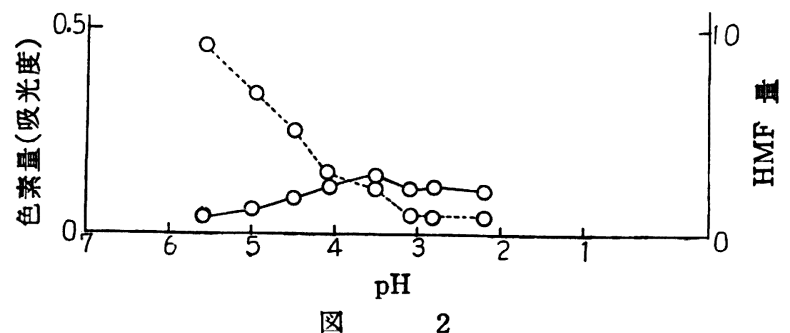

実舶: HMF 量 $(\mathrm{mg} / 100 \mathrm{cc})$, 破泉: 色䋈量 $10 \mathrm{~mm}$ 七ル

図 2 は $100^{\circ} \mathrm{C}$ (沸滕湯浴中) で約 12 時間加熱反応させたもの である。図 2 の結果からみてる $\mathrm{pH} 3.5$ 付近に HMF が多く生成 されていることになる。

このように着色量および HMF 量の生成量を表わするのが特異

11) 吉弘, 中村, 工化 61, 972 (1958).

12) 吉弘, 中村, 工化 62, 208 (1959). 
な曲線を示している原因は, 緩衝液の $\mathrm{pH}$ のみによるものでな く，その綬衝液を構成する塩類そのるのによるかも知れない。塩 類そのものに原因があるとすれば組成の異なった別の緩衝夜を用 いたときには全く別の結果にならなければならない。この点をた しかめるために $0.1 \mathrm{~N}$ 酒石酸と $0.1 \mathrm{~N}$ 酒石酸ナトリウムを種々 に混合して作成した緩衝液を使用し，同じ実験を行なった結果を 因3に示す。

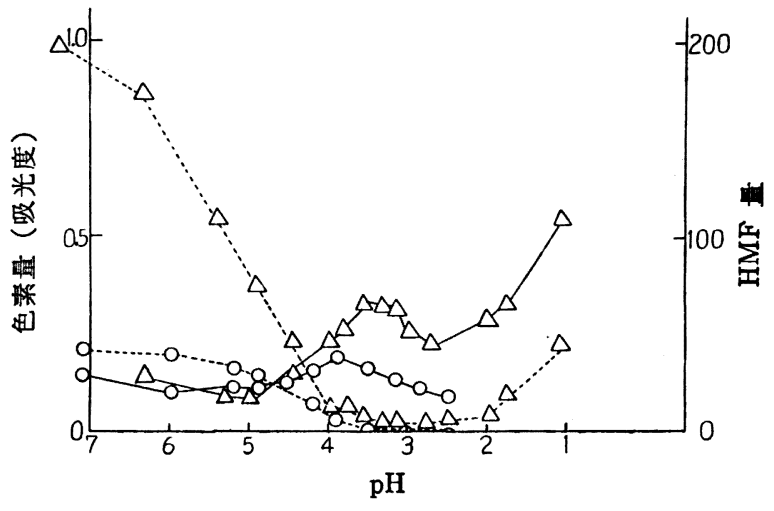

図 3

垁線：HMF $(\mathrm{mg} / 100 \mathrm{cc})$ ，破線：色岪量 $10 \mathrm{~mm}$ 七ル

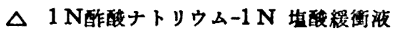

○ $0.1 \mathrm{~N}$ 酒石酸一 $0.1 \mathrm{~N}$ 酒石酸ナトリウム㩔得液

図3の結果をみてもやはり $\mathrm{pH} 3.5 \sim 4.0$ で HMF 量が多く あらわれ，色素量も酰酸ナトリウム，塩酸混合液による緩衝液を 用いた場合と同様な傾向を示している。HMF 量の極大を表わす $\mathrm{pH}$ 值が若干異なるのは緩衝液をつくる塩が異なるためであるう。

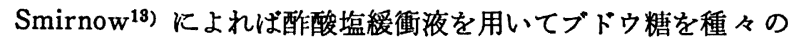
$\mathrm{pH}$ で $100^{\circ} \mathrm{C}$ で加熱するとき $\mathrm{pH} 2 \sim 4$ でブドウ糖の分解率が最 小であることを述へているが，色素の生成量からみればこの報告 と一致する。しかし，反応液中に存在する HMF 量を示す曲線が pH 3〜4 で一つの極大点をとる理由については不明である。

また，図 3 で示されるように着色量および HMF 量が 2 種の綬 衝液ではかなり異なっている。この原因は緩衝液をつくる塩の濃 度が異なることによるものと考兄られる。

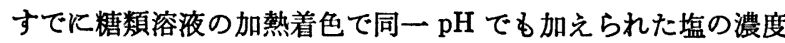
が異なる場合には生成される色素量が異なることの報告3) はある が HMF の生成量がいかになるかの報告はない。

この点に関して酶酸塩綏衝液を使用して色素量および HMF 量 と塩濃度との関係について簡単な追試を行なった。すなわち， $1 \mathrm{~N}$ 酶酸ナトリウム水溶液, $1 \mathrm{~N}$ 塩酸混合液扰よび $0.5 \mathrm{~N}$ 酢酸 ナトリウム水溶液, $0.5 \mathrm{~N}$ 塩酸混合夜拈よび $0.1 \mathrm{~N}$ 酢酸ナトリ ウム水溶液, $0.1 \mathrm{~N}$ 塩酸混合夜と, 塩濃度の異なる 3 種の酶酸塩

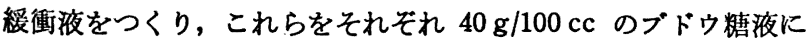
粕液と等量ずつ混合したすのについて加熱着色を行ない，色素 量, HMF 量を求めたものである。その結果を图 4 亿示す。

困 4 の結果をみると色素量が多くなる $\mathrm{pH}>4$ や，HMF 量が 多くなる $\mathrm{pH} 3.5$ 付近ではそれぞれ緩衙液の塩の濃度が大きく影 锌していることがわかる。

この結果から考劣るといわゆる中性と称せられる程度のブドウ

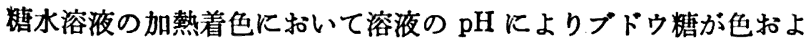
び HMF へ变化しやすいある状態が定まり，これに塩類の作用が

13) W.A. Smirnow, Stärke 10, 1 (1958).

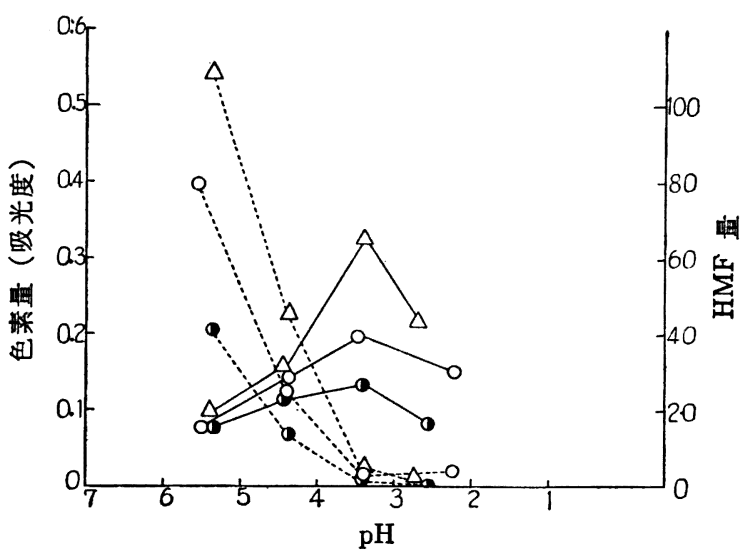

図

実線: HMF 量 $(\mathrm{mg} / 100 \mathrm{cc})$, 破線：色素量 $10 \mathrm{~mm}$

$\triangle 1 \mathrm{~N}-\mathrm{CH}_{3} \mathrm{COONa}-1 \mathrm{~N}-\mathrm{HCl}$ 楥徫没

O $0.5 \mathrm{~N}-\mathrm{CH}_{3} \mathrm{COONa}-0.5 \mathrm{~N}-\mathrm{HCl}$ 楥街浮

- $0.1 \mathrm{~N}-\mathrm{CH}_{3} \mathrm{COONa}-0.1 \mathrm{~N}-\mathrm{HCl}$ 䅑街液

加わるのではないかと推定される。すなわち， $\mathrm{pH}$ が同じであれ ば溶液に含まれる塩類の濃度汇応して着色および HMF の生成が 行なわれるが, その塩類の濃度の影響は溶液の $\mathrm{pH}$ によって異な るものと考えられる。すなわち, 溶夜の水素イオン濃度が糖液の 着色には極めて重要な因子をなしていると考えられる。

これらの関係を再確認するため反応液に含まれる酢酸ナトリウ ムの量を一定にした実験を行なった。すなわち $1 \mathrm{~N}$ 酢酸ナトリ ウム水溶液を各 $50 \mathrm{cc}$ ずつとり，これに最終溶液が $\mathrm{pH} 2 \sim 7 \mathrm{~K}$ なるように $1.15 \mathrm{~N}$ の塩酸をいろいろの量を加え水で $250 \mathrm{cc}$ K 定容して $\mathrm{pH} 2 \sim 7$ の溶液とした。これらを各 $10 \mathrm{cc}$ ずつとり 40 $\mathrm{g} / 100 \mathrm{cc}$ のブドウ糖容液 $10 \mathrm{cc}$ に加えて加熱着色を行なった。 酷酸ナトリウムの反応液中の濃度は $0.1 \mathrm{~mol} / \mathrm{l}$ となる。加熱は $135^{\circ} \mathrm{C}(2 \mathrm{~atm})$ で 1 時間行なった。その結果を図 5 亿示す。

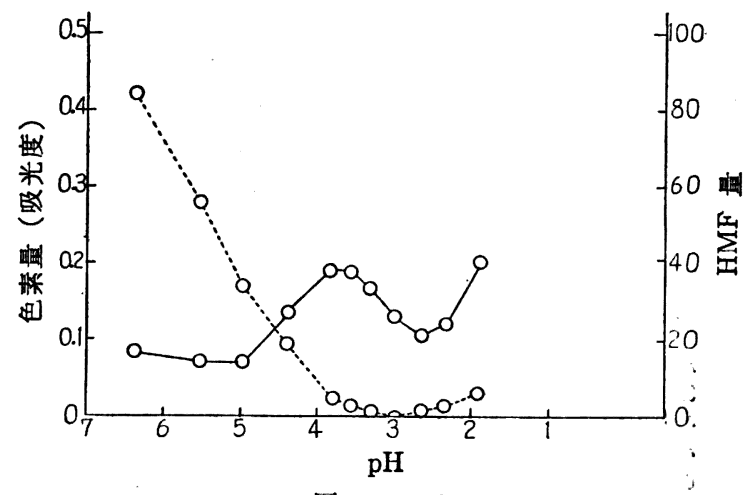

図 5

头線: HMF 㬈 $(\mathrm{mg} / 100 \mathrm{cc})$, 破線: 色类是 $100 \mathrm{~mm}$ 七ル

図 5 の結果は塩濃度を一定にした場合であるから，色蛙よび $\mathrm{HMF}$ の生成は $\mathrm{pH}$ のみによることになろう。

ブドウ糖を純水に $20 \mathrm{~g} / 100 \mathrm{cc}$ の濃度に溶解し, $134^{\circ} \mathrm{C} て ゙ 60$ 分間加熱したとき生成する色素量と HMF 量（反応液中に残存す る量）を求め，緩㣫液の場合と比較した結果を表 1 亿示す。

表 1 の結果からみると溶媒仙純水を使用したときは反応が進を につれて液の $\mathrm{pH}$ が少し下がるから，その影響も考虑しなければ ならないが着色が極めて少ないことを示している。

HMF の生成量が塩頑の存在した場合と比較して着色量ほど顕 著な差が見られないことは図 4 で推定されたよ $5 に ， \mathrm{pH}>4$ では 


\begin{tabular}{|c|c|c|c|c|c|}
\hline & & 媒 & $\begin{array}{c}\text { 表 } \\
\text { 反応前 } \mathrm{pH}\end{array}$ & 色秦量 & HMF 量 \\
\hline \multicolumn{2}{|r|}{ 純 } & 水 & 6.89 & 0.034 & 28.6 \\
\hline \multirow{2}{*}{\multicolumn{2}{|c|}{ 楥街液 }} & $\mathbf{A}$ & 6.89 & $0.92 \mathrm{a}$ & $40.0 \mathrm{a}$ \\
\hline & & $\{\mathrm{B}$ & 6.89 & $0.20 \mathrm{a}$ & $26.0 \mathrm{a}$ \\
\hline \multirow{3}{*}{\multicolumn{2}{|c|}{$\begin{array}{ll}\text { ただし } & \mathbf{A} \\
& \mathbf{B} \\
& \mathbf{a}\end{array}$}} & \multicolumn{4}{|c|}{$1 \mathrm{~N}-\mathrm{CH}_{3} \mathrm{COONa}+1 \mathrm{~N}-\mathrm{HCl}$} \\
\hline & & \multicolumn{4}{|c|}{$0.1 \mathrm{~N}$ 酒石酸ナトリウム $+0.1 \mathrm{~N}$ 酒石酸 } \\
\hline & & \multicolumn{4}{|c|}{ 因 3 より求めた数字 } \\
\hline
\end{tabular}

ブドウ糖が HMF に変化しにくい状態にあるためと考えられる。

\section{$3 \cdot 2$ HMF 溶液の加熱について}

ショ糖より Haworth ${ }^{14)}$ の方法によって作成した HMF を用 い, 種々の $\mathrm{pH}$ の緩衝液で加熱した場合, 溶液がいかに着色し てゆき，HMF がどれ位消失してゆくかについての検討を行なっ た。

表 2 は $1 \mathrm{~N}$ 酢酸ナトリウム， $1 \mathrm{~N}$ 塩酸を混合して作成した緩 衝液に HMF を溶解し $135^{\circ} \mathrm{C}(2 \mathrm{~atm})$ で 60 分間加熱したとき の結果を示したものである。 HMF 濃度は $70.0 \mathrm{mg} / 100 \mathrm{cc}$ とし た。これは $20 \%$ 糖液をこの緩衝液で加熱した場合に定量される HMF 量に準じたものである。

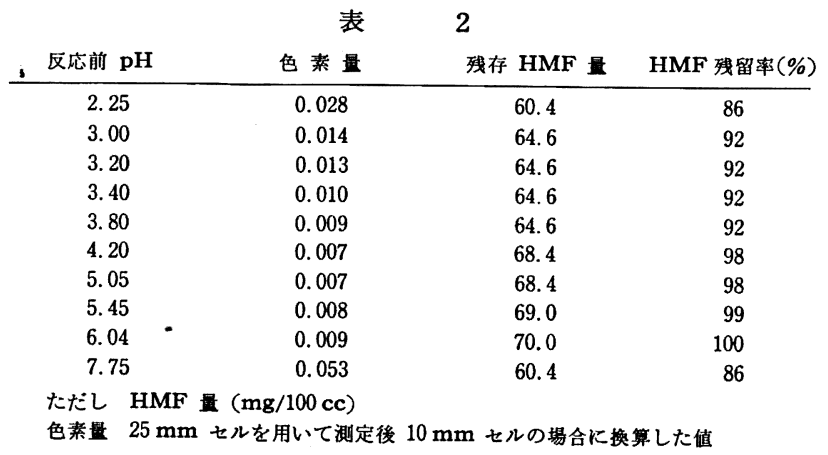

表 2 の結果からみると HMF はいわゆる中性溶液 $\mathrm{pH}>7$ では 極めて安定である。色も糖液の場合には $\mathrm{pH}>4$ では急速に生成 されたが HMF 溶液の場合はほとんど増加しない。

$0.1 \mathrm{~N}$ 酒石酸ナトリウムと $0.1 \mathrm{~N}$ 酒石酸を混合して作成した 緩衝液を用いて，同様な実験を行なった結果を表 3 に示す。この 場合の $\mathrm{HMF}$ 濃度は $68.0 \mathrm{mg} / 100 \mathrm{cc}$ とし, 加熱温度は $135^{\circ} \mathrm{C}(2$ atm), 加熱時間は 60 分である。

\begin{tabular}{|c|c|c|c|}
\hline 反応前 $\mathrm{pH}$ & 表 & $\begin{array}{l}3 \\
\text { 残存 } \mathrm{HMF} \text { 量 }\end{array}$ & HMF 残留率(\%) \\
\hline 2.80 & 0.013 & 62.0 & 91 \\
\hline 3.25 & 0.009 & 67.0 & 98 \\
\hline 4.00 & 0.007 & 68.0 & 100 \\
\hline 4.70 & 0.006 & 67.0 & 98 \\
\hline 6.45 & 0.007 & 64.0 & 94 \\
\hline
\end{tabular}

ただし HMF 量 $(\mathrm{mg} / 10 \mathrm{cc}$ ), 色素量 $10 \mathrm{~mm}$ セル使用 (吸光度)

表 3 の結果からみても HMF は安定であり，しかもこれから生 成される色は少ない。

表 2 と表 3 を比較すると HMF の消失は塩の濃度にはあまり影 響がないよ5に推定される。塩濃度を一定にした場合の HMF 溶 液の加熱着色と HMF の消失をしらべた結果を表 4 亿示す。すな わち, HMF 水溶液に酢酸ナトリウム, 塩酸を加えて HMF の緩 衝液をつくり，この溶液中の酢酸ナトリウムの濃度を $0.05 \mathrm{~mol} / \mathrm{l}$ とした。これを $135^{\circ} \mathrm{C}(2 \mathrm{~atm}) 60$ 分間加熱した結果である。た

14) W. N. Haworth, W. G. M. Jones, J. Chem. Soc. 667 (1944).

\begin{tabular}{|c|c|c|c|}
\hline 反応前 $\mathrm{pH}$ & $\begin{array}{r}\text { 表 } \\
\text { 色秦量 }\end{array}$ & $\begin{array}{l}4 \\
\text { 残存 HMF 莗 }\end{array}$ & HMF 残留事(\%) \\
\hline 2.57 & 0.009 & 31.6 & 94 \\
\hline 3.47 & 0.006 & 32.8 & 97 \\
\hline 3.76 & 0.006 & 33.6 & 100 \\
\hline 4.49 & 0.007 & 31.6 & 94 \\
\hline 5.54 & 0.005 & 32.0 & 98 \\
\hline 6.27 & 0.007 & 31.2 & 93 \\
\hline
\end{tabular}

だし $\mathrm{HMF}$ 濃度 $33.6 \mathrm{mg} / 100 \mathrm{cc}$ とした。

これらの結果から考察するとブドウ糖のいわゆる中性溶液を加 熱した場合にブドウ糖から HMF が生成されても，それが単独に 色の原因になってゆく割合は極めて小さいものと推察される。

3.3 フドウ糖と HMF の混合水溶液の加熱着色について

前報1)に拈いてはブドウ糖から生成される HMF 量を理論的に 求め，それが色になってゆくとしての理論着色量を計算し，実測 值と比較した結果から HMF のみが単独に色の原因にはなり難い ことを報告した。

しかし，この場合はブドウ糖から生成される HMF が単独に色 に変化するものであるとい5前提のもとに理論が進められたもの であって，生成された HMF が多量に残存するブドウ糖の影響を 受けないるのとした。もしブドウ糖から生成される HMF が残存 するブドウ糖と作用し，色の原因となるとすれば図1で示される ように $\mathrm{pH}>4$ で着色量が極めて多く, HMF 量が少なくても当 然となる。

しかしすでに Wolfrom ${ }^{15)}$ らはブドウ糖と HMF の混合物を水 溶液にし加熱した場合の色と，ブドウ糖，および HMFをそれぞ れ単独に水溶液として加熱した場合の色を比較した結果, ブドウ 糖, HMF 混合物の場合に目立った発色は認められないと報告し ている。また, Bergdoll16) らもショ糖水溶液の加熱着色に执い て HMF の生成は認めても, HMF をショ糖に加えたものの溶液 を加熱した場合に着色に及ぼす HMF の影響は認められなかった と報告している。前者の報告では HMF とブドウ糖の量的関係は ブドウ糖水溶液を加熱した場合に測定される HMF 量とブドウ糖 量の関係よりはるかに異なって扣り，乙かもその水溶液の $\mathrm{pH}$ は かぎられたものでしかない。後者の報告はブドウ糖水溶液の場合 ではない。それ故にこの点について明らかにする目的で HMF と ブドウ糖を混合した水溶液の加熱着色と, ブドウ糖のみの水溶液 の加熱着色とを比較した。すなわち, 酢酸ナトリウム, 塩酸より なる緩衝液にブドウ糖濃度 $20 \mathrm{~g} / 100 \mathrm{cc}$ に溶かしたもの，および HMF を加えたものについて加熱着色を行ない，色素量および

\begin{tabular}{|c|c|c|c|c|c|}
\hline \multirow{3}{*}{$\begin{array}{c}\text { 反応前 } \\
\mathrm{pH}\end{array}$} & \multirow{2}{*}{\multicolumn{2}{|c|}{$\begin{array}{l}\text { 表 } \\
\text { HMF }\end{array}$}} & \multicolumn{2}{|l|}{5} & \multirow{3}{*}{ 色素量 } \\
\hline & & & \multicolumn{2}{|l|}{ 量 } & \\
\hline & 反虑前 & 反応後 & 增加量 & 差 & \\
\hline 4.98 & $\left\{\begin{array}{c}0 \\
37.0\end{array}\right.$ & $\begin{array}{l}13.4 \\
48.6\end{array}$ & $\begin{array}{l}13.4 \\
11.6\end{array}$ & 1.8 & $\begin{array}{l}0.140 \\
0.148\end{array}$ \\
\hline 5.22 & $\left\{\begin{array}{c}0 \\
37.0\end{array}\right.$ & $\begin{array}{l}11.0 \\
44.4\end{array}$ & $\begin{array}{r}11.0 \\
7.4\end{array}$ & 3.6 & $\begin{array}{l}0.174 \\
0.185\end{array}$ \\
\hline 5.55 & $\left\{\begin{array}{c}0 \\
37.0\end{array}\right.$ & $\begin{array}{r}9.2 \\
41.2\end{array}$ & $\begin{array}{l}9.2 \\
4.2\end{array}$ & 5.0 & $\begin{array}{l}0.230 \\
0.245\end{array}$ \\
\hline 5.87 & $\left\{\begin{array}{c}0 \\
37.0\end{array}\right.$ & $\begin{array}{l}11.8 \\
40.2\end{array}$ & $\begin{array}{r}11.8 \\
3.2\end{array}$ & 8.6 & $\begin{array}{l}0.280 \\
0.290\end{array}$ \\
\hline 6.28\{ & $\left\{\begin{array}{c}0 \\
37.0\end{array}\right.$ & $\begin{array}{l}13.4 \\
40.2\end{array}$ & $\begin{array}{r}13.4 \\
3.2\end{array}$ & 10.2 & $\begin{array}{l}0.327 \\
0.331\end{array}$ \\
\hline
\end{tabular}

15) M. L. Wolfrom, R. D. Schuetz, L. F. Cavalieri, J. Am. Chem. Soc. 71, 3518 (1949).

16) M.S. Bergdoll, E. Holmes, Food Research 16, 50 (1951); Chem. Abst. 45, 4951 c. 
HMF 量を測定した。その結果を表 5 亿示す。加熱は $135^{\circ} \mathrm{C}$ (2 atm）で 60 分間行なった。

表 5 飞拈ける反応液中の酶酸ナトリウム濃度は $0.05 \mathrm{~mol} / l$ で ある。表 5 の中で差と記したのは加熱反応において，あらかじめ HMF を加えた場合と加之ない場合について反応後の HMF 量の 增加量の差を表わす。すし HMF が全然分解しないならば，この 差は零にならなければならない。

しかし，色については大きな影響はない。すなわち HMF があ ってもなくてもブドウ桾溶液の着色量には大差はない。吸光度で 表わされた色素量の数值には差があるが，これらは肉眼的には識
別できない程度のものである。

以上の結果を総括すればブドウ糖のいわゆる中性溶液を加熱し た場合に生ずる色は溶液の $\mathrm{pH}$ と重要な関係にあり, $\mathrm{pH} 3 \sim 4$ て 着色が最小となる。また，ブドウ糖から生成される $\mathrm{HMF}$ 量と $\mathrm{pH}$ の関係には特異なるのがあり, $\mathrm{HMF}$ 生成量曲線を書くと $\mathrm{pH}$ 3.6 付近で一つの極大点を示す。

着色機構についてはブドウ糖の酸性溶液の場合と同様に HMF が主原因とは考えられない。

な技実験に御協力を頂いた日幕幸一郎氏に深謝する。

\title{
重合用触媒-オレフィン付加化合物の吸収スペクトルによる研究
}

(昭 和 34 年 8 月 6 日受 理)

\author{
松 本 忠也・堤
}

\section{繁*}

重合用触媒として知られている $\mathrm{AlCl}_{3}$ の触媒機構を追求する目的で $\mathrm{AlCl}_{3}$ とオレフィンの錯化合物を研究の対象とし， あわせてチーグラー触媒を分光学的に研究した。

$\mathrm{AlCl}_{3}$ をベンゼン中に㗭濁させ，オレフインを通じると有色の錯化合物が得られる。これらの錯化合物の紫外扰よび赤 外吸収スペクトルを求め，その熱分解ガスの成分をマススペクトルによって探索した。その結果オレフインは錯化合物中 で $\mathrm{C}=\mathrm{C}$ 結合をな扰保有しており，単量体として $\mathrm{AlCl}_{3}$ と結合していることがかかた。

チーグラー触媒の場合は $\mathrm{TiCl}_{4}$ と $\mathrm{Al}\left(\mathrm{C}_{2} \mathrm{H}_{5}\right)_{3}$ の付加体をシクロへキサン中に分散させプロ パンガスを通じ，その前後 の赤外吸収スペクトルから触媒機構について若干の知見を得た。

\section{1 緒言}

いわゆるZeise の塩をはじめとし古くから金属化合物とオレフ インの配位化合物は数多く知られている1)。しかしエチレンなど のオレフインは遊離電子対を持たないのでアンモニアなどの通常 の配位子のように簡単に金属と配位結合するとは考光られない。

このようなことからもオレフィン配位化合物は触媒化学との関 連だけでなく重要なものである。

Chatt らは2)配位結合の考方方を発展させて従来どほり配位子 から二つの電子を金属へ与兄る場合と，金属の $d$ 電子から配位子 一電子を与兄る場合とに分類して考劣オレフイン配位化合物を説 明した。すなわち $\mathrm{Pt}$ や $\mathrm{Pd}$ のように $d$ 電子を有する金属の塩 化物では比較的安定なオンフイン配位化合物が得られ，これを単 雖精製して赤外吸収スペクトルやX線によってその構造を明らか にしている報告もあるす。また，金属の塩化物が次の上うに平面 構造であればオンフインと錯化合物をつくるといわれている。ま た $\mathrm{AlCl}_{3}$ や $\mathrm{FeCl}_{3}$ などは前者のような平面構造をとるのでオレ<smiles>Cl[Ge]1(Cl)[Al][W](Cl)(Cl)[GeH2]1</smiles>

* 大阪大学工学部 : 大阪市東区杉山町.

1) Zeise, Ann. 9, 632 (1827); Keller, Chem. Rev. 28. 229 (1941); Chatt, J.Chem. Soc. 1949, 3340 ; Anderson, J. Chem. Soc. 1934, 971 ; J. Chem. Soc. 1936, 1042; Lucas, J.Am. Chem. Soc. 59, 45(1937); J. Am. Chem. Soc. 60, 836(1938); Pitzer, J.Am. Chem. Soc. 67, 1126 (1945).

2) Chatt, Nature 165, 637 (1950); J. Chem. Soc. 1955, 4456.
フィンと反応して錯化合物をつくる可能性がある。

しかるに $\mathrm{AlCl}_{3}$ のそれに関しては今までに知られていない。た だ古く Kachler がエーテルと塩化第二鉄から $\mathrm{FeCl}_{2} \cdot \mathrm{C}_{2} \mathrm{H}_{4} \cdot \mathrm{H}_{2} \mathrm{O}$ を合成した時 $\mathrm{AlCl}_{3}$ る同様に試みたが失敗したと述べている。

$2 \mathrm{C}_{2} \mathrm{H}_{5} \mathrm{OC}_{2} \mathrm{H}_{5}+2 \mathrm{FeCl}_{3} \longrightarrow 2 \mathrm{FeCl}_{2} \cdot \mathrm{C}_{2} \mathrm{H}_{4}+2 \mathrm{C}_{2} \mathrm{H}_{5} \mathrm{OH}+\mathrm{Cl}_{2}$ またエチレンと $\mathrm{FeBr}_{2}$ から $\mathrm{FeBr}_{2} \cdot \mathrm{C}_{2} \mathrm{H}_{4} \cdot 2 \mathrm{H}_{2} \mathrm{O}$ が得られたとい 了報告もある文。そこで著者らは重合用触媒としてよく知られて いる $\mathrm{AlCl}_{3}$ の触媒機構を追求する目的で $\mathrm{AlCl}_{3}$ とオレフインの 錯化合物を合成し研究の対象とし，あわせてチーグラー触媒をる 分光学的に研究した。

\section{$2 \quad \mathbf{A l C l}_{3}$ ーオレフィン化合物}

\section{$2 \cdot 1$ 実 験}

$2 \cdot 1 \cdot 1$ 製法 無水塩化アルミニウムをペンゼン中に懸濁させ 温度を $60^{\circ} \mathrm{C}$ 付近でオレフィンを $3 \sim 4$ 時間通じ，一夜放置後ま たオレフインを 1〜2 時間通じるとエチレンの場合は緑黄色，プ ロピレンの場合は赤褐色の油状物質が得られる。この油状物質を ベンゼンから分離し四塩化炭素などの溶剤で洗い, 時計血へ滴下 すると針状結晶として析出してくる。湿気の多い空気にふれると $\mathrm{HCl}$ ガスを放出して分解する。

$2 \cdot 1 \cdot 2$ 紫外部吸収スペクトル 上述のようにして得た物質を アルコールに溶かし紫外部吸収スペクトルを求めると図 1 のよ5 になる。

3) Chatt, J.Chem. Soc. 1953, 2939; Baenziger, J.Am. Chem. Soc. 77, 4984 (1955).

4) Kachler, Ber. 2, 510 (1869); Chojnacki, Z.Chem. 2, 6,419 (1870). 